\title{
PERANCANGAN PROTOTYPE ALAT PENGURANG KADAR AIR PADA MADU KAPASITAS 5 LITER
}

\author{
Achmad Kusairi Samlawi'), Wahyu Slamet Pamungkas ${ }^{1)}$ \\ 1,2Program Studi Teknik Mesin, \\ Fakultas Teknik Universitas Lambung Mangkurat \\ JL. Akhmad Yani Km.36 Banjarbaru, Kalimantan Selatan,70714 \\ Telp. 0511-4772646, Fax 0511-4772646 \\ E-mail: wahyuslem23@gmail.com
}

\begin{abstract}
The quality of Honey must meet the requirements set by the Indonesian National Standard (SNI) in 2004. In the standard set, the enzyme diastase function is at least $3 \mathrm{DN}$, hydroxymethylfurfural (HMF) maximum $50 \mathrm{mg} / \mathrm{kg}$, maximum air content is $22 \% \mathrm{~b} / \mathrm{b}$, sugar reducing at least $65 \% \mathrm{~b} / \mathrm{b}$, asucrose maximum $5 \% \mathrm{~b} /$ $b$, acidity maximum 50 milliecivalents $/ \mathrm{kg}$, solids not up to maximum $0.50 \% \mathrm{~b} / \mathrm{b}$, maximumAash content $0.50 \% b / b(B S N)$, 2004) To meetAthese standards designedAa tool that willAreduce the air content in honey without damaging it as it is vaccinated at $-70-70$ bar with temperatures below $40^{\circ} \mathrm{C}$. With the results of the balance shows: (1) electric motor with power 1/4 HP with $1400 \mathrm{rpm}$ rotation. (2) $V$-belt transmission with large outside pulley dimensions $=231.3 \mathrm{~mm}$, small outer plley $=104 \mathrm{~mm}$. Using a v-belt with no. 44 in $/ 1118 \mathrm{~mm}$. Horizontal shaft with dimensions of large pulley shaft diameter $=18 \mathrm{~mm}$ and small pulley shaft diameter $=15 \mathrm{~mm}$. (3) Using a gearbox damper with a ratio of 1:40. (4) Stirrer shaft with 304 grade stainless steel material with a length of $975 \mathrm{~mm}$ and a shaft diameter of $40 \mathrm{~mm}$. (5) Stirrer impeller with six blade impeller type with dimensions of diameter 1667, $\mathrm{mm}$ and thickness of $3 \mathrm{~mm}$. (6) Vessels with cylindrical types and having a thickness of $2.5 \mathrm{~mm}$, a diameter of $500 \mathrm{~mm}$ and a length of $500 \mathrm{~mm}$. With an ellipsoid head type with dimensions of $520 \mathrm{~mm}$ in diameter, $125 \mathrm{~mm}$ in height and $2.5 \mathrm{~mm}$ in thickness. (7) Frame with a profile of mild steel profile dimension dimensions of $40 \mathrm{~mm} \times 40 \mathrm{~mm} \times 2.5 \mathrm{~mm}$.
\end{abstract}

Keywords: Design, Prototype, Air Reducer in Honey

\section{PENDAHULUAN}

Mutu Madu harus memenuhi ketentuan yang ditetapkan oleh Standar Nasional Indonesia (SNI) tahun 2004. Dalam SNI ditetapkan standar mutu madu sebagai berikut: aktivitas enzim diastase minimal $3 \mathrm{DN}$, hidroksimetilfurfural (HMF) maksimal $50 \mathrm{mg} / \mathrm{kg}$, kadar air maksimal $22 \% \mathrm{~b} / \mathrm{b}$, gula pereduksi minimal $65 \% \mathrm{~b} / \mathrm{b}$, sukrosa maksimal $5 \% \mathrm{~b} / \mathrm{b}$, keasaman maksimal 50 miliekivalen $/ \mathrm{kg}$, padatan tak larut maksimal $0,50 \% \mathrm{~b} / \mathrm{b}$, kadar abu maksimal $0,50 \% \mathrm{~b} / \mathrm{b}$ (BSN, 2004).

Kadar air yang berasal dari jenis madu nectar karet pada suhu ruang menunjukkan diatas kadar maksimal menurut SNI tahun 2004, yaitu sebesar $22 \%$. Hal ini bisa dapat dipengaruhi oleh beberapa faktor penyebab. Kadar air madu yang dipengaruhi oleh kelembaban lingkungan. Hal ini dikarenakan madu mempunyai sifat higroskopis, yaitu keadaan dimana madu mudah menyerap air. Tingginya kelembaban lingkungan maka kadar air madu akan semakin tinggi pula (Wulandari, 2017). Jika kelembapan 51\%, kadar air madu 16,1\%.

Madu yang mengandung kadar air sedikit akan menjaga kualitas madu tetap baik untuk jangka waktu yang lama. Prasetya dan Andi (2014) menjelaskan 
bahwa kandungan kadar air yang tinggi pada madu akan merangsang aktifitas khamir untuk tumbuh.

Proses pemanasan pada madu dapat menyebabkan terjadinya karamelisasi warna madu menjadi lebih gelap, penurunan flavor dan aroma, naiknya suhu madu sehingga menyebabkan manipulasi buruk selama penyimpanan dan dapat menyebabkan lebih tingginya kadar hydroxymenthylfurfural (MHF). Cara pemanenan dan pemrosesan madu yang kurang tepat dapat menurunkan kualitas madu itu sendiri. Bila pengolahannya tepat dan baik maka nilai Gizi madu akan tetap tinggi, sedangkan pemrosesan madu tanpa pemasakan atau dalam suhu rendah akan menjamin seluruh gizi tetap utuh.

Dalam perancangan alat pengurang kadar air pada madu ini, alat terdiri dari berbagai komponen, motor listrik, transmisi, bejana tekan, tutup atau head bejana tekan, poros pengaduk, serta impeller pengaduk.

Material yang digunakan pada komponen - komponen yang bersentuhan dengan madu menggunakan jenis Stainless Steel (SS) hal ini dilakukan untuk mencegah terjadinya korosi pada komponen. Dan jenis stainless steel yang di gunakan adalah SS Grade Food 304.

Stainless Steel grade 304 adalah jenis baja yang tahan terhadap karat austenitic, stainless steel memiliki komposisi $0.006 \% \mathrm{~S}, 1.19 \% \mathrm{Mn}, \quad 0.034 \% \mathrm{P}$, $0.049 \% \mathrm{Si}, 8.15 \% \mathrm{Ni}, 18.24 \% \mathrm{Cr}, 0.042 \% \mathrm{C}$, dan sisanya Fe. Stainless Steel jenis ini memiliki sifat mekanik antara lain: elongation $50 \%$, yield strength $270 \mathrm{Mpa}$, kekerasan $82 \mathrm{HRB}$, kekuatan tarik $646 \mathrm{Mpa}$. Baja jenis ini memiliki berbagai keguanaan kaerna sifat tahan karatnya. Baja jenis ini juga memiliki kualitas sangat baik dalam hal kekuatan mekanik, komposisi kimia, kemampuan las dan ketahanan korosinya dengan harga yang terjangkau. Baja jenis ini memiliki banyak fungsi dan banyak di gunakan dalam berbagai hal. Seperti komposisi pembuatan tanki dan kontainer, farmasi, kimia, pertambangan serta peralatan makanan.

\section{METODE PERANCANGAN \\ Motor Listrik}

Torsi motor listrik yang di gunakan :

$P_{\text {motor }}=2 \cdot$.T.n. T $_{\text {motor }}$

\section{Bejana tekan / Head}

1. Bejana yang di rancang untuk menahan tekanan $-70 \mathrm{~mm} / \mathrm{Hg}$.

Dengan volume bejana:

$\mathrm{V}=\pi \cdot \mathrm{r}^{2} . \mathrm{t}$

Dengan ketebalan bejana adalah :

$\mathrm{t}=\frac{P \cdot R}{S \cdot E-0.6 \cdot P}+\mathrm{CA}$

2. Head yang di gunakan adalah jenis Ellipsodal Head dengan dimensi :

$\mathrm{t}=\frac{P \times D}{2 . S \cdot E-0.2 \cdot P}+\mathrm{CA}$ 


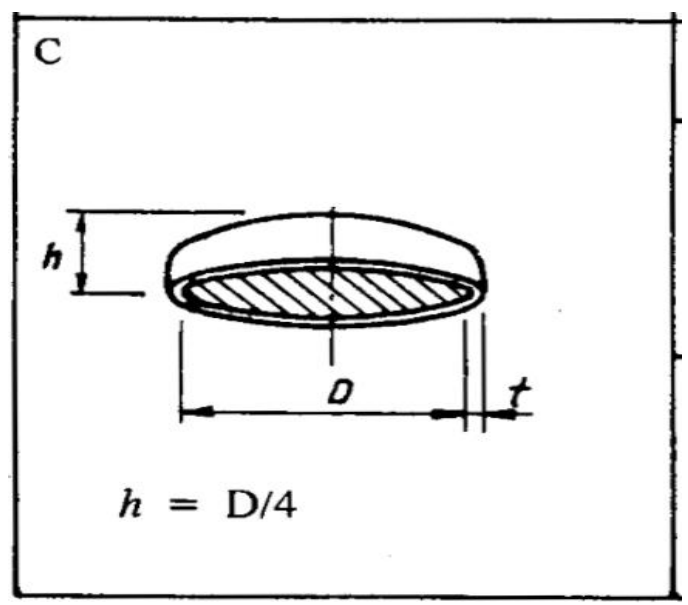

Gambar 1. Ellipsoidal Head

\section{Pengaduk / Impeller}

Pengaduk / impeller digunakan untuk mengaduk campuran, dengan rumus untuk mencari ukuran pengaduk / impeller kita harus mengetahui terlebih dahulu reynold number dan number power melalui persamaan:

$\mathrm{N}_{\mathrm{RE}}=\frac{\rho \cdot \mathrm{N} \cdot \mathrm{D}^{\wedge} 2}{\mu}$

$\mathrm{N}_{\mathrm{P}}=\frac{\mathrm{P} \cdot \mathrm{gc}}{\rho \cdot n^{3} \cdot D^{\wedge} 5}$

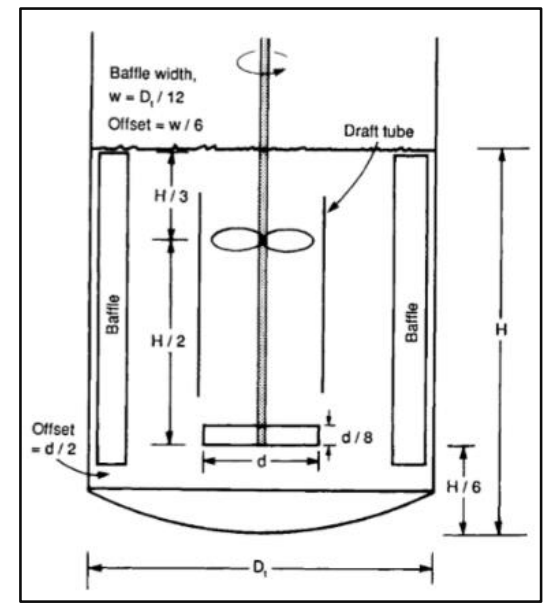

Gambar 2. Dimensi pengaduk / impeller

$$
\begin{aligned}
& \frac{D A}{D T}=\frac{1}{3} \\
& \frac{E}{D A}=1 \\
& \frac{W}{D A}=\frac{1}{5}
\end{aligned}
$$




\section{Poros Pengaduk}

Dimensi poros pengaduk adalah sebagai berikut :

1. Momen pada poros:

$\mathrm{T}=9,74 \times 10^{5} \frac{\mathrm{P}_{\mathrm{d}}}{\mathrm{n}_{1}}$

2. Mencari tegangan geser yang diizinkan:

$\tau_{a}=\frac{\sigma_{B}}{S f_{1} \times S f_{2}}$

3. Perhitungan besar diameter poros:

$d_{s}=\left[\left(\frac{5,1}{\tau_{a}}\right) \cdot K_{t} \cdot C_{b} \cdot T\right]^{\frac{1}{3}}$

\section{Bantalan}

Dimensi dan umur bantalah adalah sebagai berikut :

1. Beban equivalent yang di terima bantalah adalah :

$W_{e}=\left(X_{R} \cdot v \cdot W_{R}+Y_{T} \cdot W_{T}\right) \cdot K S$

2. Umur bantalah adalah :

$L=60 \times n_{2} \times L_{H}$

\section{Transmisi}

Transmisi yang digunakan adalah jenis sabuk - V:

1. Dengan kecepatan sabuk:

$V=\frac{\pi \cdot d_{p} \cdot n_{1}}{60 \times 1000}$

2. Dengan panjang sabuk:

$L=2 C+\frac{\pi}{2}\left(D_{P}+d_{p}\right)+\frac{1}{4 C}\left(D_{P}+d_{p}\right)^{2}$

3. Panjang keliling sabuk:

$L=2 C+\frac{\pi}{2}\left(D_{P}+d_{p}\right)+\frac{1}{4 C}\left(D_{P}+d_{p}\right)^{2}$

4. Diameter Pulley:

$d_{k}=d_{p}+2 \times 5,5$

$D_{k}=D_{p}+2 \times 5,5$

\section{METODE PENELITIAN}

Metode yang digunakan pada penelitian ini adalah jenis metode perencanaan berdasarkan:

A. Identifikasi masalah

Identifikasi masalah disini merupakan proses awal perencanaan alat pengolah madu. Dari identifikasi ini akan di kumpulkan masalah-masalah atau kekurangan pada alat yang sudah ada.

\section{B. Analisis masalah}

Setelah mengetahui masalah dan kekurangan alat pengolah madu yang sudah ada, maka akan di lakukan analisis permasalahan untuk mendapatkan solusi yang sesuai dengan apa yang dibutuhkan, solusi ini akan diterpkan pada alat pengolah madu yang akan di rancang ini. 
C. Konsep desain

Pada konsep desain ini berasal dari identifikasi dan analisis serta mempertimbangkan beberapa aspek-aspek terkait dengan analisis teknis serta perkiraan harga produksi.

D. Uji Kualitas Analisa Software

Pada tahap ini, konsep desain yang telah di tuangkan ke dalam gambar 3D akan di analisis dengan menggunakan software.

E. Modifikasi

Dalam modifikasi ini untuk merubah perhitungan dan rancangan yang telah di lakukan namun belum memenuhi standar yang telah di tentukan.

Dari hal - hal di atas perancangan di mulai dari perhitungan secara manual untuk mencari tau jenis material serta ukuran setiap komponen yang akan di gunakan, lalu di lanjutkan dengan pembuatan model 3D menggunakan software Autodesk Fusion 360 dan beberapa simulasi pada rangka alat yang menggunakan software Autodesk Inventor Profesional.

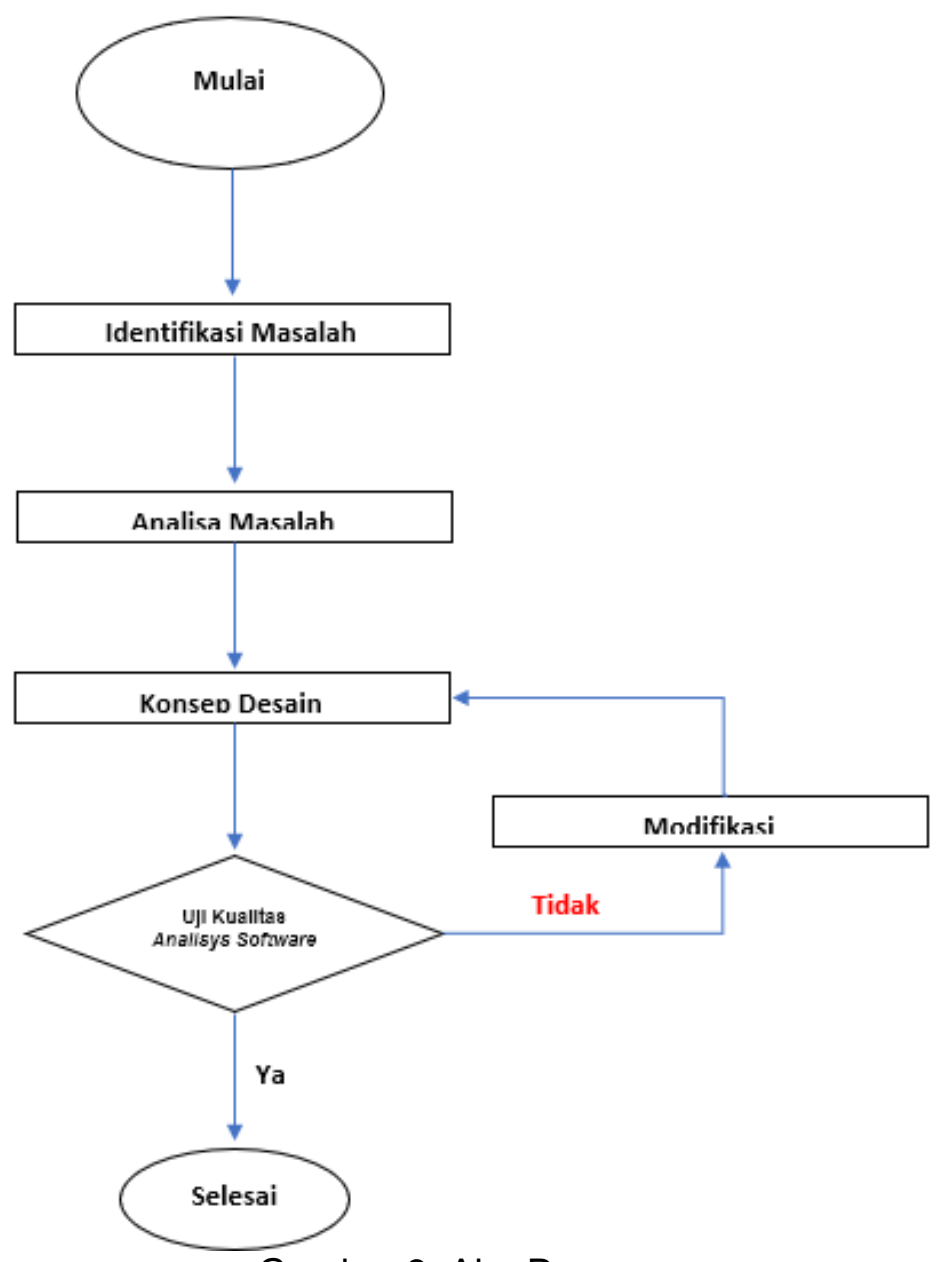

Gambar 3. Alur Perancangan

\section{HASIL DAN PEMBAHASAN}

Dari hasil perancangan yang di lakukan, di dapat hasil perancangan seperti motor listrik, transimisi, bejana tekan. Head/tutup bejana tekan,Poros pengaduk, 
Impeller, serta rangka dengan spesifikasi komponen serta dimensi komponen sebagai berikut:

Spesifikasi umum motor listrik yang digunakan adalah motor listrik dengan daya $1 / 4 \mathrm{Hp}$ dengan putaran $1400 \mathrm{rpm}$.

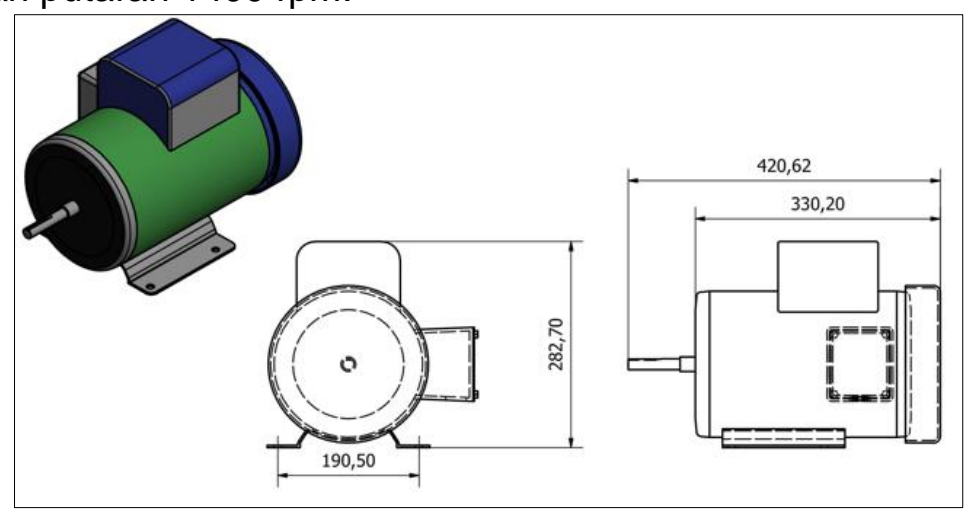

Gambar 4. Motor Listrik

Dimensi transmisi yang digunakan adalah sebagai sebagai berikut:

Diameter luar pulley besar $=231,3 \mathrm{~mm}$

Diameter luar pulley kecil $=104 \mathrm{~mm}$

Jenis sabuk

= Sabuk-V dengan tipe $\mathrm{A}$.

Keliling sabuk

$=1118 \mathrm{~mm}$

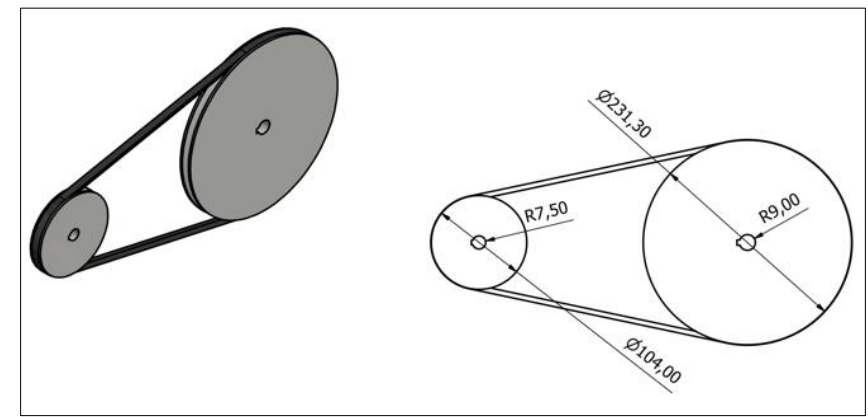

Gambar 5. Transmisi V-Belt

Dimensi bejana tekan yag digunakan adalah sebagai berikut:

Diameter luar

$=555 \mathrm{~mm}$

Diameter dalam $\quad=500 \mathrm{~mm}$

Tebal

$=2 \mathrm{~mm}$

Panjang

$=502,50 \mathrm{~mm}$

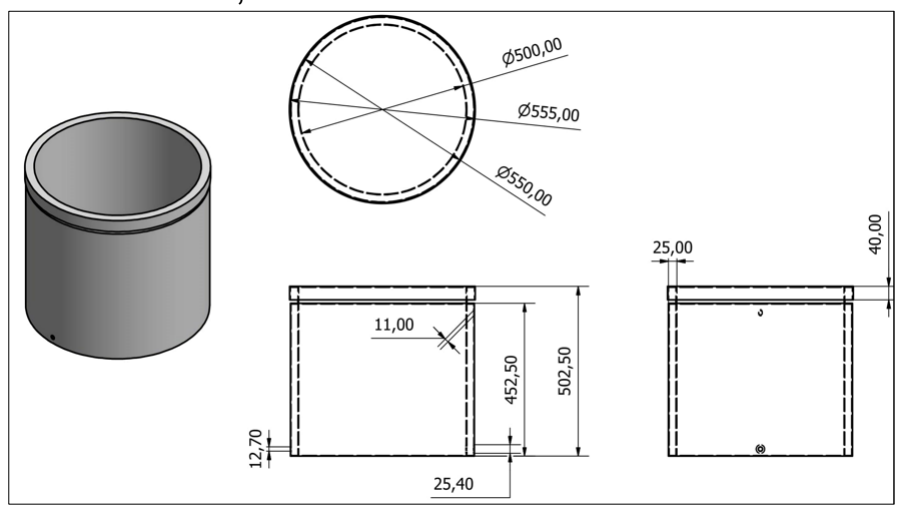

Gambar 6. Alur Perancangan 
Dimensi tutup / head bejana tekan adalah sebagai berikut:
Diameter
$=570 \mathrm{~mm}$
Tebal
$=2 \mathrm{~mm}$
Radius
$=250,11 \mathrm{~mm}$

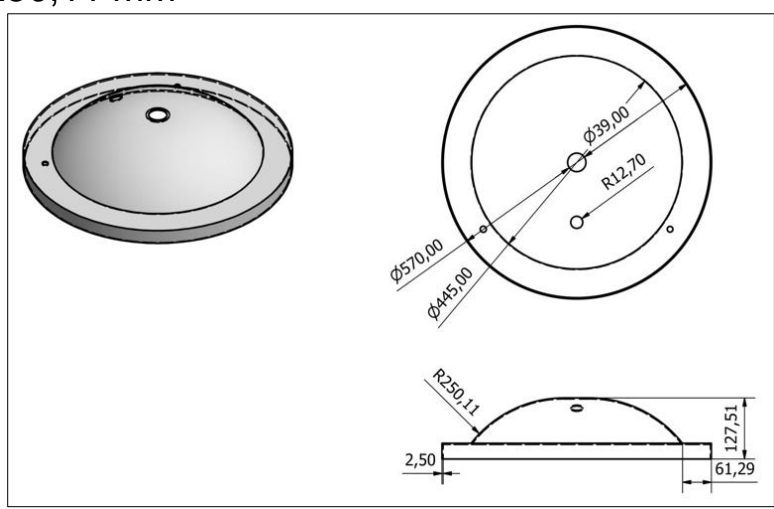

Gambar 7. Tutup / Head Bejana Tekan

Dimensi poros pengaduk yang digunakan adalah sebagai berikut:

Diameter $\left(\mathrm{d}_{1}\right)=30 \mathrm{~mm}$

$\left(d_{2}\right)=27 \mathrm{~mm}$

Panjang $=976.80 \mathrm{~mm}$

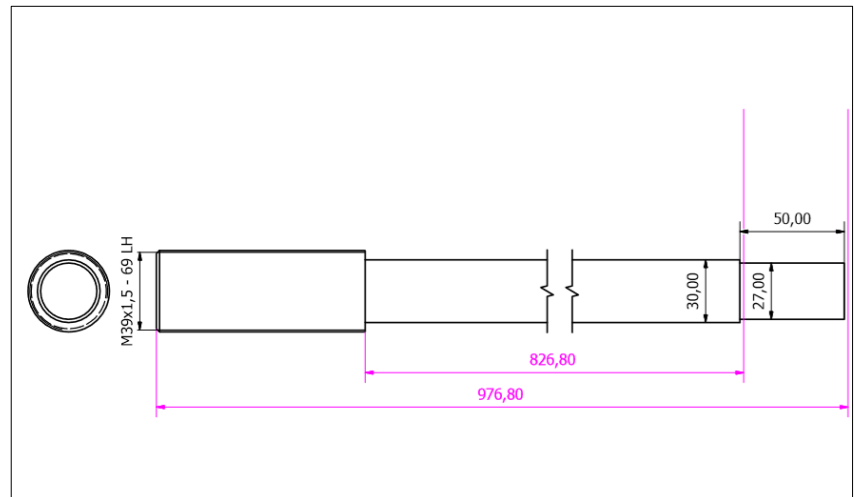

Gambar 8. Poros Pengaduk

Dimensi impeller yang digunakan adalah sebagai berikut:
Diameter
$=416 \mathrm{~mm}$
Tinggi
$=100 \mathrm{~mm}$
Tebal
$=4 \mathrm{~mm}$

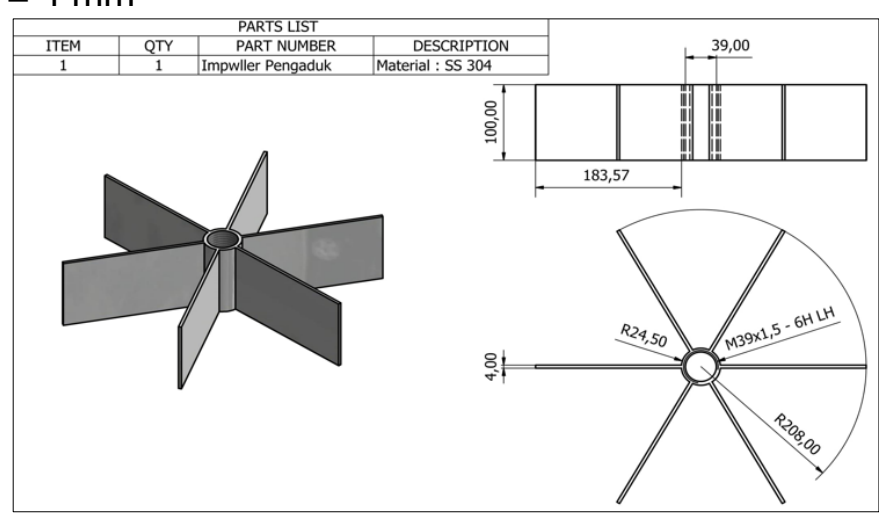

Gambar 9. Impeller 
Spesifikasi dan dimensi pada rangka utama adalah sebagai berikut:
Panjang
$=1300 \mathrm{~mm}$
Lebar
$=1185 \mathrm{~mm}$
Tinggi
$=2040 \mathrm{~mm}$
Profil rangka
$=$ Profil Persegi
Tebal material rangka $=2 \mathrm{~mm}$

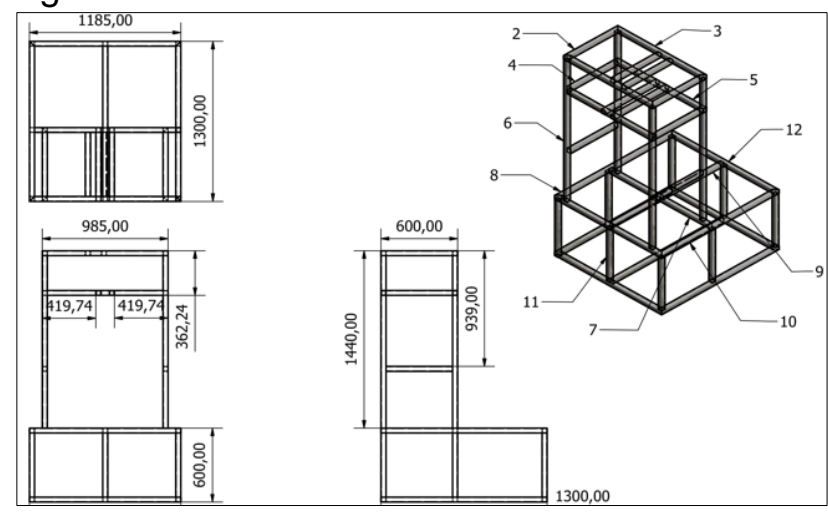

Gambar 10. Rangka

Berikut adalah desain Assembly Full dengan dan tanpa cover dari hasil rancangan yang di visualisasikan menggunakan software desain:

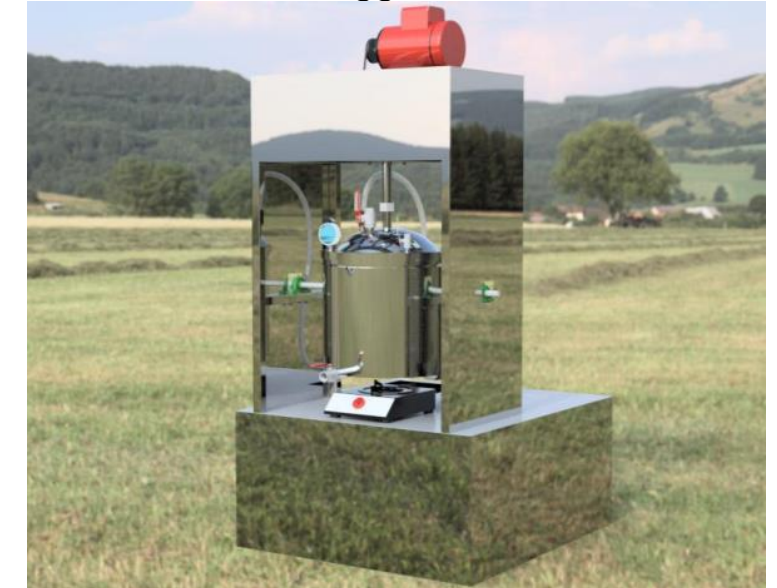

Gambar 11. Assembly Full Alat View Isometric

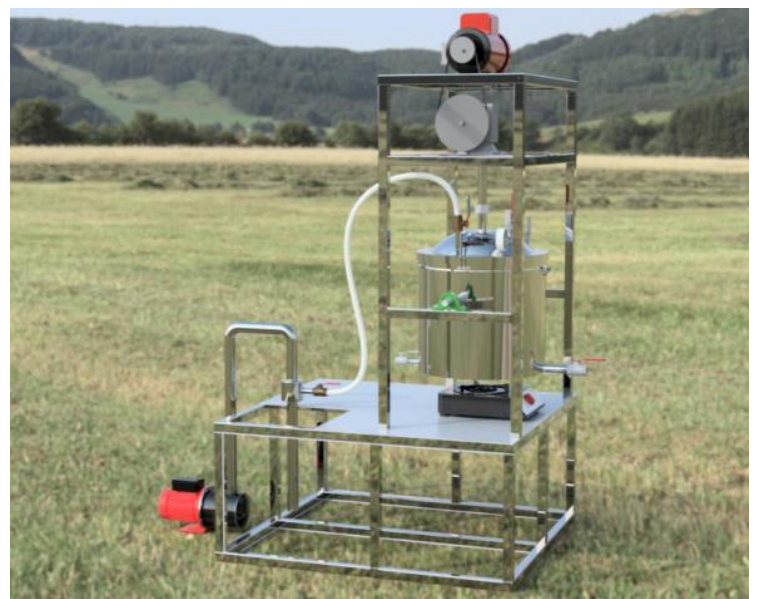

Gambar 12. Assembly Full Alat Tanpa Cover Tampilan Dari Samping 


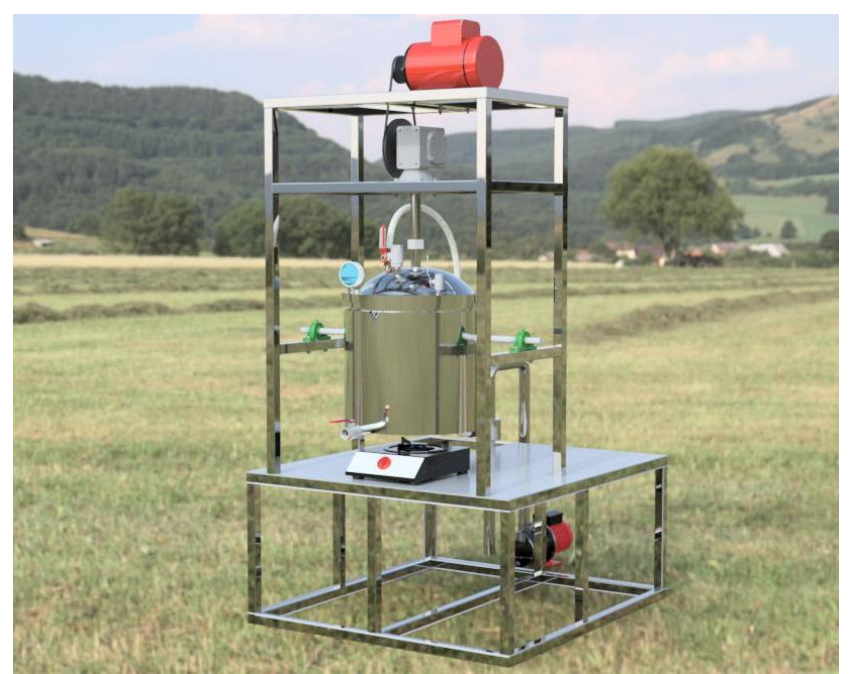

Gambar 13. Assembly Full Tanpa Cover View Isometric

\section{PEMBAHASAN}

Hasil perancangan alat pengurang kadar air pada madu berkapasitas 5 liter ini dapat di simpulkan bahwa, motor listrik yang digunakan sebagai penggerak utama adalah motor listrik dengan daya $1 / 4$ HP dan memiliki putaran $1400 \mathrm{rpm}$ dengan transmisi yang di pilih adalah $v$-belt dengan dimensi pulley luar besar $=$ $231,3 \mathrm{~mm}$, pulley luar kecil $=104 \mathrm{~mm}$. Menggunakan $v$-belt dengan no 44 in / $1118 \mathrm{~mm}$. Menggunakan poros perantara dengan dimensi diameter poros pulley besar $=18 \mathrm{~mm}$ dan diameter poros pulley kecil $=15 \mathrm{~mm}$. Menggunakan reducer gear box sebagai penurun kecepatan dari $600 \mathrm{rpm}$ ke $15 \mathrm{rpm}$ dengan rasio 1:40 untuk mengurangi kecepatan putaran awal motor agar sesuai dengan yang di rencanakan dan menggunakan poros pengaduk dengan material stainless steel grade food 304 dengan panjang $975 \mathrm{~mm}$ dan diameter poros $40 \mathrm{~mm}$ dengan Impeller pengaduk yang digunakan adalah jenis impeller six blade dengan dimensi diameter $1667, \mathrm{~mm}$ dan ketebalan $3 \mathrm{~mm}$. Serta dimensi bejana yang di gunakan adalah jenis silinder dan memiliki ketebalan $2,5 \mathrm{~mm}$, diameter $500 \mathrm{~mm}$ dan panjang $500 \mathrm{~mm}$. Dengan jenis head ellipsoidal dengan dimensi diameter $520 \mathrm{~mm}$, tinggi $125 \mathrm{~mm}$ dan ketebalan $2,5 \mathrm{~mm}$ dan menggunakan rangka yang di gunakan dalam alat pengurang air pada madu berkapasitas 5 liter ini menggunakan material steel mild profil persegi dimensi $40 \mathrm{~mm} \times 40 \mathrm{~mm}$ × 2,5 $\mathrm{mm}$. 


\section{DAFTAR PUSTAKA}

Adi Santoso Pribadi dan Rizal Bahrul Chamidi (2015), Mahasiswa Program Studi Diploma III Teknik Mesin Produksi. Institut Teknologi Sepuluh November, Surabaya. 'Rancang Bangun Mesin Pengaduk Adonan Donat'.

Devyana Dyah Wulandari (2017). Mahasiswa Fakultas Kesehatan. Universitas Nahdlatul Ulama, Surabaya. 'Kualitas Madu (Keasaman, Kadar Air dan Kadar Gula Pereduksi) Berdasarkan Perbedaan Suhu Penyimpanan.

Edwin Yunanto (2015). Mahasiswa Teknik Mesin. Universitas Negeri Yogyakarta, Yogyakarta. 'Perancangan Pengkristal Gula Jawa'

Eugene F. Megyesy, Pressure Vessel Handbook. : Oklahoma, Pressure Vessel Publishing.INC : 2001.

Imam Al Hakim, dkk (2016). Mahasiswa Jurusan Keteknikan Pertanian, USU, Medan. 'Rancang Bangun Alat Pengaduk Sabun Cair Bagan Baku Minyak Jelantah'.

K. Ratnayani, N.M.A Dwi Adhi S, dkk (2008). Mahasiswa Fakultas Matematika dan IImu Pengetahuan Alam, Universitas Udayana. Bukit Jimbaran, 'Penentuan Kadar Glukosa Dan Fruktosa Pada Madu Randu dan Madu Kelengkeng Dengan Metode Kromatografi Cair Kinerja Tinggi'.

Mz Arif (2017). Mahasiswa Fakultas Kedokteran. Universitas Lampung. Lampung. 'Pengaruh Madu Terhadap Luka Bakar'.

McCabe L. Warren, Julia C.Smith and Peter Harriot, Unit Operations Of Chemical Engineering:: New York, Librari of congress cataloging : 1993.

Nuzulia Khoiriah, dkk. (2016). Mahasiswa Teknik Mesin. UNISSULA, Semarang. "Perancangan Alat Pemeras Madu dengan Mempertimbangkan Faktor Ergonomi dan Waktu Proses Pemerasan".

Neng Sri Novi, dkk (2016). Jurusan Teknik Industri Fakultas Sains dan Teknologi UIN Suska. Riau. "Studi Kasus: Kecamatan Tapung Kabupaten Kampar Riau".

Nazarudin, dkk (2017). Mahasiswa Teknik Mesin. Universitas Riau, Riau. : 'Perancangan Vacuum Evaporator Penurun Kadar Air Dalam Madu Kapasitas 50 Liter'.

Prendis Betha Nanda, dkk. Mahasiswa Fakultas Peternakan. Universitas Brawijaya, Malang. 'Perbedaan Kadar Air, Glukosa Dan Fruktosa Pada Madu Karet Dan Madu Sonokeling'.

Sepya Ayu Catur Pamungkas, dkk (2016). Mahasiswa Pendidikan Teknik Mesin, Universitas Negeri Semarang, Semarang. "Rancang Bangun Mesin Pengaduk Mentega (churner) dengan Speed Control',".

Sularso dan Kiyokatsu Saga, Elemen Mesin, Technical Colage Japan : AKA, 2017. 